\title{
Wage Differentials by Firm Size: The Efficiency Wage Test in a Developing Country
}

\author{
Tatiane Almeida de Menezes \\ Professora - Universidade Federal de Pernambuco (UFPE) \\ Endereço: Av. dos Economistas, s/n - Cidade Universitária - Recife - Brasil \\ CEP: 50670-901 - E-mail: tatianedemenezes@gmail.com

\section{Isabel Pessoa de Arruda Raposo} \\ Pesquisadora - Fundação Joaquim Nabuco \\ Endereço: Rua Dois Irmãos, 92 - Apipucos - Recife - Brasil \\ CEP: 52071-440 E-mail: isabel.raposo@fundaj.gov.br
}

Recebido em 11 de janeiro de 2012. Aceito em 09 de outubro de 2013.

\begin{abstract}
Using data from the Brazilian Labor Monthly Survey (PME/ IBGE) for the years of 2006 and 2007, the paper investigates if the wage differential by firm size in Brazil can be explained by the predictions of the Efficiency Wage Theory. It is adopted a Switching Regression Model to estimate if large size companies pay a higher wage premium for dispended labor effort, as compared to smaller enterprises. The results prove the EW predictions since they evidence positive relationships between wages and labor effort, schooling and longer job duration. However, such findings are not sufficient to explain the existence of wage differentials by firm size in the Brazilian labor market.
\end{abstract}

\section{Keywords}

efficiency wage, labor effort, firm size, wage differentials

\section{Resumo}

Usando dados da Pesquisa Mensal de Emprego (PME/ IBGE) para os anos de 2006 e 2007, este artigo investiga se a diferença de salários por tamanho de firma no Brasil pode ser explicada pela Teoria do Salário Eficiência. Estimações de Switching Regression são utilizadas para verificar se as empresas de grande porte pagam um prêmio salarial maior aos seus funcionários por esforço despendido, comparativamente às pequenas empresas. Os resultados corroboram as predições do Salário Eficiência, uma vez que revelam uma relação positiva entre salário e esforço laboral e também entre escolaridade e duração no posto de trabalho. No entanto, esses resultados não são suficientes para explicar o diferencial de salários existente entre grandes e pequenas empresas no mercado de trabalho brasileiro.

\section{Palavras-Chave}

salário eficiência, esforço laboral, tamanho da firma, diferenciais de salário

\section{Classificação JEL}

J01, J31 


\section{Introduction}

Empirical evidences demonstrate that different size enterprises pay different wages (Ahn, 2006; Fox, 2004; Arbache, 2001; WinterEbmer and Zweimüller, 1999; Romanguera, 1991; Brown and Medoff, 1989; US Department of Commerce Bureau of the Census, 1988, 1988; Barth et al., 1987). Most of them provide two sources of explanations. From one side, wage differentials by firm size arise because of firm and worker's heterogeneity, and from the other side, companies with high monitoring costs pay higher salaries than the market clearing level (the Efficiency Wage Theory). In this paper we are particularly interested in verifying if the prediction of the EW theory, on its shirking version, can explain the wage differentials among different size firms in Brazil.

According to competitive theories, the occurrence of wage dispersion for similar workers would be basically a consequence of measurement problems in empirical estimations. Features that are not directly captured in the datasets, such as individual's ability or nonpecuniary worker preferences, cannot be incorporated in wage determination models.

For quite different mechanisms, the Efficiency Wage (EW) theory demonstrates how a wage distribution (for similar workers) can arise in equilibrium. The EW models incorporates the idea that enterprises would get better economic results if they remunerate their employees with a higher wage than the market clearing level and there are various reasons why the firms would behave in such a way. In the shirking version proposed by Shapiro and Stiglitz (1984), firms that face high monitoring costs, such as the large companies, find shirking so costly that the payment of high wages is a proper incentive to extract labor effort.

The existence of efficiency wage is supported by large empirical evidences (Rebitzer, 1995; Groshen and Krueger, 1990; Krueger and Summers, 1987 and 1988; Dickens and Katz 1987a and 1987b, and Groshen, 1986). In Brazil, it is worth mentioning three references. The work of Arbache (2001) found that unmeasured abilities and efficiency wage models played a role in the inter-industrial wage differentials for the decades of 1980s and 1990s. He estimated a significant and positive correlation between firm size and wage 
differentials. Esteves (2008 and 2006) corroborated the efficiency wage theory by estimating a negative relationship between salary and intensity of supervision for several Brazilian industries in 2003 and 2004.

Most of the works in the literature frequently utilizes two proxy variables for labor effort: (i) firm size and (ii) the ratio of supervisors/ employees. The problem with both proxies is that it is based on the restrictive hypothesis of exogeneity, when in the reality the amount of monitoring, supervisors and salaries are simultaneously determined by the firm. It is difficult to justify that in the profit maximization process, firms can choose the wages, but do not have any control on the quantity of supervisors per employee (Esteves, 2006).

The present article offers a new contribution in the analysis of efficiency wage by proposing the use of new proxy variables for the effort level, and distinct econometric method and dataset. The information about Sub-Occupation and Sub-Remuneration reported in the Brazilian Labor Monthly Survey (PME/ IBGE) is being adopted as the proxies for the level of labor effort. The advantage of using the PME survey is that it selects individuals from both the formal and informal labor market and this is an important assessment, given the expressive presence of the informal sector in Brazil.

The relationship between firm size and salaries is estimated by using longitudinal data for Brazilian workers in 2006 and 2007 and a switching regression model, which is a technique that permits to control for the problem of individual self-selection into specific job occupations. The results have corroborated the presence of efficiency wages in the Brazilian labor market, since it was found a direct relationship between work effort and salaries. However, the wage premium paid for greater dedication to the jobs was not statistically different between large and small size companies.

The rest of the paper is organized as follows. The next section introduces a literature review about the EW models emphasizing on the developments of the shirking version. The following one presents the estimation strategies based on the switching model described in Cameron and Trivedi (2005) and discusses some endogeneity problems of econometric estimations. The fourth section brings the data 
used for the estimations and briefly describes some characteristics of the Brazilian Labor Monthly Survey (PME/ IBGE). The results obtained are presented in the fifth and the last section concludes the paper.

\section{Literature Review on Efficiency Wage Models}

Unlike the Walrasian approach, the EW theory is based on the premise that there are social and nonmarket aspects related to the production process that might push the wages above the market clearing level. Bowles (1985) refers to the models based on such premise as neo-Hobbesian because the concept of malfeasance, also known as shirking or free riding, is crucial to understanding the internal structure of the firm. ${ }^{1}$

This author departs from the capital-labor relationship in the Marxian model and provides microeconomic foundations to explain the behavior of workers and firms. He demonstrates that the existence of a non-Walrasian wage would be a result of two specific aspects of the interaction between capital and labor. First, the employers-workers relationship would be marked by a conflict of interest in which the firm's profits could be enhanced by being able to compel the worker to act in a manner that he or she otherwise would not choose. The second characteristic of the capital-labor interaction is that the strategies that capital may adopt in order to enhance or exercise its power over labor are costly. The employer can increase the probability of detecting employee malfeasance through dispending resources on surveillance personnel and equipment. It will be clear as follows how these concepts of shirking and intensity of supervision can give rise to the efficiency wage and the predicted trade-off between salaries and monitoring technology.

There are various versions of the EW models that explain why it is profitable for an employer to fix the wage above the market clearing level and each of them exploit different mechanisms on the relation among worker, employer and the market forces. Romanguera (1991)

1 According to Bowles (1985), the agent's opportunistic behavior would give rise to the Hobbesian problem of reconciling self-interested behavior on the part of individuals with collective or group interests. 
lists seven distinct approaches for the EW models, which will be briefly described below:

- Nutritional Model: the earliest of these models. It was developed by Leibenstein (1957) and established that the positive correlation between effort and wage would be motivated by the worker's health and nutrition that could be achieved by highest consumption supported by higher salaries.

- Adverse Selection Model: predicts that better workers have better alternative offers and that the high wage firms increase the probability of attracting a better pool of applicants (Weiss, 1980, apud Romanguera, 1991).

- Recruiting Model: emphasizes that firms find costly to have a job offer turned down because of recruitment costs and forgone production, therefore the entrepreneur has an incentive to catch the applicant by offering an elevated salary (Lang, 1988 and Montgomery, 1988, apud Romanguera, 1991).

- Sociological or Normative Model: relies on the idea that agents are not completely individualistic in their choices, but also value social conventions that are not totally individualistic. As a consequence, the worker perceives his or her higher remuneration as a "gift" to be rewarded with more dedication to the job (Solow, 1979 and 1980; Akerlof, 1982 and 1984; and Akerlof and Yellen, 1988, apud Romanguera, 1991).

- Union Threat Model: argues that collective action enables workers with bargaining power that allows them to appropriate part of the firm's rents, which in turn leads to higher wages (Dickens, 1986 apud Romanguera, 1991).

- Turnover Model: it is very similar to the shirking version that will be presented next. This model assumes that labor turnover is costly for the firm because they lose the investments made on the job training and because workers have lower productivity in the adjustment process. As a result, firms in order to minimize such costs have incentive to prevent turnover by paying higher salaries (Salop, 1979 and Stiglitz, 1974, 1985 apud Romanguera, 1991).

- The shirking version: it was proposed by Shapiro and Stiglitz (1984) and bases its structure on the following intuition: if unemployment represents a penalty for those who were caught shirking, then workers will choose not do so. The employers, on their side, in order to avoid shirking have in- 
centive to pay more than the "going wage", thus if all firms act similarly the labor demand will reduce and, therefore, unemployment arises. Note that the employers cannot monitor the activities of their employees costlessly and perfectly and that is why high wage represents savings for the firm both in monitoring costs and in the increased output due to higher effort. Therefore, there is an informational problem between employers and workers in the structure of this model that explains how involuntary unemployment can persist as an equilibrium phenomenon.

\section{The Basic Model of the Shirking Version (Shapiro and Stiglitz, 1984)}

The model starts assuming that there are a fixed number of $\mathrm{N}$ identical workers who dislikes exerting labor effort and enjoy consumption, with utility represented by $U(w, e)$, where $w$ is the wage earned and $e$ is the level of effort put on the job activities. When an individual is unemployed, he or she receives a benefit of $w^{b}$ and $e=0$. There is a probability $b$, taken as exogenous, that a worker can be dismissed from the job due to relocation, for example, but not because he or she was caught shirking. However, if the employee shirks, there is some probability $q$ that he or she will be caught and fired. The worker utility is maximized at a discount rate of $r>0^{2}$.

The only choice the worker makes is the selection of the effort level, by comparing the utility of shirking $\left(V_{E}^{S}\right)$ and not shirking $\left(V_{E}^{N}\right)$. The utility equations of a shirker and nonshirker are given by:

$$
\begin{gathered}
r V_{E}^{S}=w+(b+q)\left(V_{u}-V_{E}^{S}\right) \\
r V_{E}^{N}=w-e+b\left(V_{u}-V_{E}^{N}\right)
\end{gathered}
$$

where $V_{u}$ is the utility of being unemployed that will be presented latter. Working with both equations yields the following solutions:

$$
V_{E}^{S}=\frac{w+(b+q) V_{u}}{r+b+q}
$$

\footnotetext{
${ }^{2}$ When $r$ is higher, the relatively more weight is attached to the short-run gains from shirking, until one is caught, compared to the losses incurred when one is eventually caught.
} 


$$
V_{E}^{N}=\frac{(w-e)+b V_{u}}{r+b}
$$

The worker will not shirk if and only if $V_{E}^{N} \geq V_{E}^{S}$, which produces the no-shirking condition (NSC):

$$
w \geq r V_{u}+(r+b+q) e / q \equiv \hat{w}
$$

Note that the critical wage $\hat{w}$ is positively related with the effort level $(e)$, the utility of being unemployed $\left(V_{u}\right)$, the interest rate $(r)$ and with the quit rate $(b)$, but it is inversely related with the probability of being caught $(q)$.

From the employer's side, the firm has a production function $Q_{i}=f\left(L_{i}, S_{i}\right)$, where $L$ is the labor input and $S$ is the supervisory input. An enterprise pays $s$ for its supervisors and $w$ for its employees and must pay some level $w^{b}$ of unemployment benefits, which will be set at the minimum level as possible. The idea behind the EW theory is that companies might differ on their monitoring technology and, as a result, some will have incentive to pay more than the going wage.

In order to find the no-shirking condition after incorporating the firm's behavior, lets first present the utility of a worker being unemployed:

$$
r V_{u}=w^{b}+a\left(V_{E}-V_{u}\right)
$$

where $a$ is the job acquisition rate and $V_{E}$ is utility of an employed worker, which equals to $V_{E}^{N}$, in equilibrium. Solving for (4) and (6), we have:

$$
r V_{E}=\frac{(w-e)(a+r)+w^{b} b}{a+b+r}
$$




$$
r V_{u}=\frac{(w-e) a+w^{b}(b+r)}{a+b+r}
$$

Replacing (8) into the NSC (5) yields the aggregate NSC:

$$
w \geq w^{b}+e+e(a+b+r) / q
$$

Observe that the critical wage is greater, the highest $w^{b}$ and the flows out of unemployment $a$. Since $a$ is the probability of obtaining a job per unit of time, $1 / a$ is the expected duration of unemployment, so the longer this duration, the smaller the wage necessary to induce nonshirking. In steady-state the flow into unemployment, $b L$, equals the flow out, $a(N-L)$, which gives:

$$
a=b L /(N-L)
$$

Substituting for $a$ into (9), the aggregate NSC becomes:

$$
\begin{aligned}
& w \geq w^{b}+e+\frac{e}{q}\left(\frac{b N}{(N-L)}+r\right) \\
& =w^{b}+e+(e / q)(b / u+r) \equiv \hat{w}
\end{aligned}
$$

where $u=(N-L) / N$, is the unemployment rate. Market equilibrium occurs when the aggregate NSC intersects the aggregate demand for labor.

Equation (11) shows the mechanisms that induce companies to pay high salaries. From the worker's point of view, he or she wishes to keep a high remuneration because entering into unemployment represents a penalty given the lost of the high wages themselves and because with high salaries the labor demand will be low, which implies long spells of unemployment. As a result, to keep that level of labor income, workers will choose to devote the highest amount of effort necessary to reach the critical wage at NSC. 
From the firm's side, when they have control on their monitoring technologies, two outcomes are possible, firms that face high monitoring costs will have incentive to pay at least $\hat{w}$ as a worker discipline, and also because they want to keep a high level of output due to increased effort. But if the monitoring costs aren't high enough, the firms do not need to pay an elevated salary because they can easily observe workers effort and this is a sufficient mechanism for no-shirking.

\section{Empirical Strategy and Endogeneity Problems}

\subsection{Endogeneity Issues Related to the Empirical Testing of the Efficiency Wage}

The basic idea of the EW theory in its shirking version is that the payment of higher salaries and the threat of unemployment would be proper incentives to extract labor effort and such job dedication will be greater, the greater the amount of supervision inside the firm. Given that the labor effort is not readily observable, the intensity of supervision is normally used as its proxy in empirical estimations. Therefore, it is expected a trade-off between monitoring and wages.

In the setup proposed by Shapiro and Stiglitz (1984), firms choose both the wage (which guarantees the non-shirking condition) and the monitoring level $S$ (which defines the probability of being caught shirking, q). The simultaneity associated with this choice creates problems in using variables related to supervision as proxies for labor effort, because the number of supervisors would not be an exogenous variable. As argued by Esteves (2006), it is difficult to justify that in the profit maximization process, firms can choose the wages, but do not have any control on the quantity of supervisors per employee.

In addition, there is also the problem of omitted variables correlated with monitoring variables. Rebitzer (1995) demonstrates that in estimating a wage equation, the monitoring intensity is likely to be correlated with other human resource practices usually omitted in the models. Examples of such practices would be resources spent 
on employee's recruitment, screening or training, variables that do not use to be registered on datasets.

Worker's unmeasurable attributes also poses challenges for the empirical testing of EW models. As an example, different individual's ability cannot be controlled in cross section estimations. Besides, there is still the fact that the individuals might self-select themselves into specific companies since they might have non-pecuniary preferences for small firms. Some workers judge that large enterprises have a poor work environment because it has more rules, requests more intensive work or is more impersonal, thus, on the margin the employees have lower preferences for the big firms and the large employers need to pay a compensating wage to attract labor (Fox, 2004; Oi, 1983).

Another commonly used proxy for detecting labor effort is the firm size. In this case, the idea is that it would be harder to monitor a great amount of employees and the payment of higher wages would stimulate workers to devote more effort that could substitute the supervisory input. However, the use of firm size as a proxy for work dedication is also a problematic variable, because it might be the case that other factors, like the mentioned non-wage preferences for small firms, would be contributing for a positive relationship between wages and firm size.

Considering these endogeneity problems, direct OLS estimations of supervision (or firm size) on salaries would produce biased estimates for the referred effort proxies. Many authors tried to overcome such issues by proposing original solutions. Groshen and Krueger (1990) found an exogenous variable for supervision intensity in the American health sector: the amount of supervisory nurse that is regulated by law and, therefore, is not on the firm's control. Rebitzer (1995) tested the EW hypothesis for contract workers in the petrochemical industry and found a cleaner relationship between wages and supervision because there are specific institutional features surrounding the employment of such workers that guarantees the exogeneity of the monitoring variables. Esteves (2006) adopted the average job duration of supervisor workers for the Brazilian labor market, as an instrumental variable in a two-stage OLS estimation. 


\subsection{Empirical Model}

In this section we present the empirical strategy used to investigate the inter-dependence of wage and firm size given worker and firm's attributes. The hypothesis to be tested is that larger firms remunerate better the worker effort because it might be a proper strategy to minimize monitoring costs which are greater in bigger companies.

In order to investigate such question, this paper departs from the assumption that the decision of being employed can be seen as a two-part decision problem, where firstly the worker decides if she (or he) wants to work in a small or in a large firm and secondly her (or his) wage is determined. This assumption is based in Roy (1951), who considered that the existence of individual heterogeneous skills and self-selection into job occupations could create occupational differentials of earnings.

The application of the Roy Model is very suitable for the problem studied in the present paper, since it might be the case that the wage differentials by firm size could arise as a consequence of heterogeneous skills and levels of effort. According to Cameron and Trivedi (2005), the prototypical Roy model adapted to our problem is defined as follows. There is a latent variable $y_{1}^{*}$ indicating if the observed result is $y_{2}^{*}$ or $y_{3}^{*}$, such as:

$$
y_{1 i}=\begin{array}{ll}
1 & \text { iff } y_{1 i}^{*}>0 \\
0 & \text { iff } y_{1 i}^{*} \leq 0
\end{array}
$$

where $y_{1 i}^{*}>0$ if the individual $i$ works for small firm in 2006 and $y_{1 i}^{*} \leq 0$ if he or she works for medium or large companies. Based in (12) it can be defined a linear system with additive errors for the latent variable:

$$
\begin{aligned}
& y_{1 i}^{*}=z_{1 i}^{\prime} \beta_{1}+\varepsilon_{1 i} \\
& \Delta \ln y_{2 i}^{*}=x_{2 i}^{\prime} \beta_{2}+\varepsilon_{2 i} \\
& \Delta \ln y_{3 i}^{*}=x_{3 i}^{\prime} \beta_{3}+\varepsilon_{3 i}
\end{aligned}
$$


The first equation indicates if the person works or not in a small firm. The second and third equations have as dependent variable the growth of the natural logarithm of wage, between 2006 and 2007, for the individuals who work in small and large firms: $\Delta \ln y_{2 i}^{*}$ e $\Delta \ln y_{3 i}^{*}$, respectively. The vector $x_{i}^{\prime}$ is composed of exogenous variables that represent the preferences and characteristics of individuals and market, while $z_{i}^{\prime}$ is a vector of instruments. The idea behind the system present in (13) is that $x_{3 i}^{\prime} \beta_{3}=x_{2 i}^{\prime} \beta_{2}+\alpha$, where $\alpha$ is the extra-wage paid by larger enterprises for workers alike. Assuming that the correlated errors have a joint normal distribution, the simplest parametric model is given by:

$$
\left[\begin{array}{l}
\varepsilon_{1 i} \\
\varepsilon_{2 i} \\
\varepsilon_{3 i}
\end{array}\right] \sim N\left[\left[\begin{array}{l}
0 \\
0 \\
0
\end{array}\right],\left[\begin{array}{ccc}
1 & \sigma_{12} & \sigma_{13} \\
\sigma_{21} & \sigma_{2}^{2} & \sigma_{23} \\
\sigma_{13} & \sigma_{23} & \sigma_{3}^{2}
\end{array}\right]\right]
$$

As usual (14) is normalized for $\sigma_{1}^{2}=1$. The most common estimation strategy is the Heckman's two-step method applied to the truncated means:

$$
\begin{aligned}
& E\left[\ln \Delta y_{2 i}^{*} \mid\left(x_{2 i}^{\prime}, z_{1 i}^{\prime}\right), y_{1 i}^{*}>0\right]=x_{2 i}^{\prime} \beta_{2}+\sigma_{12} \lambda\left(z_{1 i}^{\prime} \beta_{1}\right) \\
& E\left[\ln \Delta y_{3 i}^{*} \mid\left(x_{3 i}^{\prime}, z_{1 i}^{\prime}\right), y_{1 i}^{*} \leq 0\right]=x_{3 i}^{\prime} \beta_{3}-\sigma_{13} \lambda\left(-z_{1 i}^{\prime} \beta_{1}\right)
\end{aligned}
$$

where $\lambda\left(z_{1 i}^{\prime} \beta_{1}\right)=\phi\left(z_{1 i}^{\prime} \beta_{1}\right) / \Phi\left(z_{1 i}^{\prime} \beta_{1}\right)$ is the inverse-Mills ratio. At the first stage, it is estimated a probit model, which binary dependent variable $\left(y_{1}^{*}\right)$ is whether the individual works or not in a small enterprise. This first-stage estimation is, thus, the selection equation and yields estimates of $\beta_{1}$ and $\lambda\left(z_{1 i}^{\prime} \beta_{1}\right)$. At the second stage, two separated OLS regressions give the estimates for $\left(\beta_{2}, \sigma_{12}\right)$ and $\left(\beta_{3}, \sigma_{13}\right)$. Maddala (1983) provides further details for this model and calls it Switching Regression Model.

An important comment is that the OLS regression of $\Delta \ln w^{*}$ on $x^{\prime}$ alone leads to inconsistent estimates of $\beta_{2}$ and $\beta_{3}$. It happens because the errors are correlated as the workers self select themselves into firms according to specific features such as the size. This, in turn, affects the wage determination. Therefore, the use of the switching 
regression method, combined with the choice of the labor effort proxy variables, to test the existence of efficiency wage is a new contribution to address to some of the endogeneity issues present in the wage determination.

\section{Data Description}

The paper uses data from the Brazilian Labor Monthly Survey (PME/ IBGE) for the years of 2006 and 2007. PME is a longitudinal survey based on a rotating panel, where a group of households is selected in every sample sector and each of these households are interviewed for four consecutive months, after that they exit the survey to come back again eight months later and be followed for four additional months. The survey covers six metropolitan regions of Brazil: Recife, Salvador, Belo Horizonte, São Paulo, Rio de Janeiro and Porto Alegre.

The target variable to be studied here is the salary paid on small and medium to large size firms, in order to check for the hypotheses of wage gap persistence as a result of EW mechanisms. The salary will not be taken in level but instead as a variation between the years of 2006 and 2007, in an attempt to mitigate for fixed effect problems related, for example, to worker's ability or non-wage preferences for the firm. The figure 1 below show the wage concentration curves in micro and medium enterprise. The results suggest that about $80 \%$ of workers received up to $\mathrm{R} \$ 500$ and until this value the workers from micro firms receive on average less than those of larger companies.

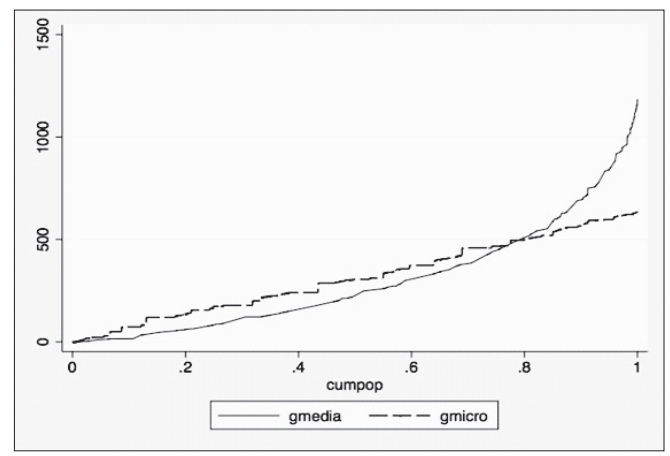

Figure 1 - Wage Curve of concentration of micro (gmicro) and medium (gmedia) Brazilian companies, between 2006 and 2007 
There are two groups of explaining variables included in the model, one capturing the usual worker's socioeconomic features, such as gender, age, head of family and education, and the other covering the characteristics of the job, such as sector of activity, type of contract (if temporary or not), legal contribution for social security, time working for the firm, and two proxy variables designed to capture the effort level of the worker: sub-occupation and sub-remuneration.

The individuals considered sub-occupied were those who worked less than 40 hours a week, but wished to work more, while sub-remuneration addressed to those employees who received a wage that was inferior to the average salary the category of similar workers used to earn. If the EW hypothesis is verified, we should expect a positive sign for both variables, given that the payment of higher salaries acts as a labor discipline for the employee.

The choice of these proxies followed the spirit of the studies of Bradley et al. (2007), Engellandt and Riphahn (2003), Booth et al (2000) and Jimeno and Cortes (1996), whose works chose as effort level proxies, unpaid overtime work or absenteeism. Note that sub-remuneration corresponds to unpaid overtime work because when the employee is sub-remunerated he or she is receives less per hour worked, being equivalent to working unpaid hours. While suboccupation can be seen as a propensity not to be absent, since the individuals reveal a desire to work more hours than they are actually doing. The use of the absenteeism variable would not be trustable in the present paper because the PME is answered by the employee and he or she would rather not reveal job absenteeism, a problem that doesn't exist when the employer, instead, is interviewed.

The selection of our database used workers employed in small firms with less than ten employees, and those employed in medium to large firms, with eleven or more workers. After the removal of missing observations, we ended up with 37,024 observations, being 6,196 workers in the small firms and 30,828 in the larger ones.

The data used for the estimations is presented in Table 1, which brings individual attributes of the worker and the job characteristics according to the firm size. 
Table 1 - Sample characteristic according to the firm size

\begin{tabular}{|c|c|c|}
\hline \multirow{2}{*}{ CHARACTERISTICS } & \multicolumn{2}{|c|}{ FIRM SIZE } \\
\hline & SMALL & MEDIUM AND LARGE \\
\hline \multicolumn{3}{|l|}{ Individuals } \\
\hline Man & $59.64 \%$ & $62.47 \%$ \\
\hline 16 to 25 years old & $30.94 \%$ & $23.29 \%$ \\
\hline 26 to 40 years old & $40.90 \%$ & $44.84 \%$ \\
\hline 41 to 70 years old & $28.16 \%$ & $31.87 \%$ \\
\hline Head of family & $43.35 \%$ & $48.93 \%$ \\
\hline Years of school & 3.07 & 3.40 \\
\hline \multicolumn{3}{|l|}{ From the job } \\
\hline Average wage & $\mathrm{R} \$ 602.66$ & $\mathrm{R} \$ 1,593.62$ \\
\hline Temporary contract & $3.94 \%$ & $4.65 \%$ \\
\hline Social security contribution & $52.94 \%$ & $84.64 \%$ \\
\hline Working for 1 month & $1.63 \%$ & $0.80 \%$ \\
\hline 1 month to 1 year of work & $22.11 \%$ & $17.25 \%$ \\
\hline 1 to 2 years of work & $15.74 \%$ & $13.88 \%$ \\
\hline Working for more than 2 years & $60.52 \%$ & $68.07 \%$ \\
\hline Sub-occupied & $3.31 \%$ & $2.13 \%$ \\
\hline Sub-remunerated & $26.74 \%$ & $8.62 \%$ \\
\hline Industry & $12.41 \%$ & $25.20 \%$ \\
\hline Construction & $8.04 \%$ & $4.47 \%$ \\
\hline Sales & $32.12 \%$ & $16.60 \%$ \\
\hline Financial & $20.56 \%$ & $20.21 \%$ \\
\hline Public administration & $7.26 \%$ & $15.44 \%$ \\
\hline$N^{\circ}$ of observations & 6,196 & 30,828 \\
\hline
\end{tabular}

Source: Labor Monthly Survey (Pesquisa Mensal de Emprego, PME/IBGE, 2006 and 2007).

Table 1 tells us that there exists some worker heterogeneity from individual and, especially, from the job aspects. Medium to large size firms employ in average a higher percentage of man, head of family and hire employees slightly more educated. The greatest difference arise in terms of the wage paid: the average salary of large firms is almost three times as greater as the one paid in small and medium enterprises.

Another striking discrepancy is the social security contribution and sub-remuneration. The highest percentage of workers under subremuneration helps to explain why the average wage of small firms is so much lower than the one paid in larger ones. 
The social security contribution, on its turn, is also expected to be inferior in small companies, since this segment of the Brazilian labor market concentrates the highest amount of the so-called "informal" business that do not pay taxes and usual legal labor costs.

Other differences important to mention, but not as remarkable as the ones just cited, refer to the labor duration and the percentage of sub-occupied workers. In average $23.74 \%$ of the labor force employed in small firms has been working for less than 1 year, against $18.05 \%$ in bigger enterprises. The percentage of sub-occupied workers is higher in small firms, as well. The distribution among economic sector is also heterogeneous by firm size: medium to large size firms concentrate labor demand on the industry segment, while small companies employ more on the sales sector

\section{The Results for the Wage Growth Estimation in Brazil using Switching Regression Model}

In this section, the key hypothesis of this paper is tested. The switching regression model is used to investigate if the predictions of the efficiency wage theory holds for Brazil. The idea is to test if large firms because of higher monitoring costs do pay a higher wage in order to extract more labor effort.

As already discussed, individuals might self select themselves into specific companies according to non-wage preferences for the firm and heterogeneous abilities. The assumption is that this choice is associated to some demographic and occupational characteristics, such as the variables presented in the selection equation in Table 2.

The results in Table 2 indicate that the probability of working in a small size enterprise decreases with age, years of school, growth of schooling and within workers who are head of family. These results are consistent with empirical evidences provided by Fox (2004), in which he argues that it is efficient to match high-ability workers together with large employers because the marginal product of a manager supervising a large firm is greater. 
Additionally, older workers or heads of family represent individuals carrying more familiar responsibilities, so they tend to be more experienced, value more the employment and, as consequence, are rather desired by more structured and large firms.

On the other hand, the chances of working on a small size enterprise increase within workers under temporary contract and who contributes for social security. For the first case, Booth et al (2000) find evidences that temporary employees present greater probability of wishing to separate (either to change occupation or geographical location) or have a higher cost (or lower benefit) in acquiring specific human capital. Considering that large size firms tend to invest more on firm-specific training in order to produce large standardized volumes of output, labor turnover can represent substantial cost for the large employer, therefore, they do not wish a worker who presents high probability of quitting.

As for the positive relation between the chances of working in a small company and social security contribution, we have an unexpected result, which is possibly associated with the recent "formalization" process in the Brazilian labor market that might be increasing the chances of a worker who benefits from social security to be employed in a small firm. In fact between 2006 and 2007, the proportion of employees who contributed to social security in small firms increased 10\%, while the growth observed in large firms was only of 3\% (PME/ IBGE, 2006 and 2007).

The geographic dummies indicate that the probability of working in a small firm decreases in the metropolitan regions of Belo Horizonte, São Paulo and Porto Alegre relatively to the reference dummy of Salvador. This is an expected result since these three cities are located in the most developed regions of Brazil, which concentrate larger and more structured companies, while Salvador is located in a poorer region. 
Table 2 - Selection equation for working or not in small/ medium firms in 2006 - First stage probit estimation

\begin{tabular}{|c|c|c|}
\hline VARIABLES & COEFFICIENT & STANDARD ERRORS \\
\hline Age & $-0.0022^{*}$ & 0.0012 \\
\hline Man & 0.0325 & 0.0247 \\
\hline School variation & $-0.2316^{\star \star *}$ & 0.0106 \\
\hline Years of school & $-0.2488^{\star \star *}$ & 0.0150 \\
\hline Head of family & $-0.0923^{\star \star \star}$ & 0.0213 \\
\hline Temporary contract & $0.0870^{*}$ & 0.0449 \\
\hline Sub-occupied & -0.0193 & 0.0713 \\
\hline Sub-remunerated & 0.0273 & 0.0360 \\
\hline Social security contribution & $0.0762^{*}$ & 0.0291 \\
\hline Working for 1 month & -0.0412 & 0.0983 \\
\hline 1 month to 1 year of work & -0.0004 & 0.0291 \\
\hline 1 to 2 years of work & 0.0030 & 0.0341 \\
\hline Industry & -0.0352 & 0.0347 \\
\hline Construction & 0.0467 & 0.0546 \\
\hline Sales & 0.0091 & 0.0357 \\
\hline Financial & -0.0334 & 0.0358 \\
\hline Public administration & -0.0285 & 0.0403 \\
\hline Belo Horizonte & $-0.1113^{\star *}$ & 0.0439 \\
\hline Rio de Janeiro & -0.0370 & 0.0417 \\
\hline São Paulo & $-0.2179^{\star * *}$ & 0.0424 \\
\hline Porto Alegre & $-0.1551^{\star \star *}$ & 0.0453 \\
\hline Recife & 0.0206 & 0.0517 \\
\hline Constant & -0.0215 & 0.0886 \\
\hline
\end{tabular}

Bold coefficients for p-value: ${ }^{* * *} \mathrm{p}<0.01,{ }^{* *} \mathrm{p}<0.05,{ }^{*} \mathrm{p}<0.1$.

Table 3 brings the estimations of the second and third equations in (13), which corresponds to the wage growth equation by firm size. The solution for the system of equations in (13), which includes the selection equation (Table 2), is simultaneously obtained by maximum likelihood estimation. Table 3 shows us how the behavior of the wage growth varies with the size of the firm.

The wage growth between 2006 and 2007 was greater amongst women and younger workers when compared to men and older individuals. It was also positively related with the increase in the years of school and with all the metropolitan regions located in the south of Brazil compared with the reference dummy, the city of Salvador. 
Only when compared to Recife, a city from the same region as Salvador, this last city exhibit greater wage growth in the case of large companies.

The wage increase was also directly associated with the period of time working for the firm, but at decreasing rates, which was expected, provided that firm cannot augment the salary at increasing rates as the worker lasts in the company. This tendency was especially clear after the first year of contract, for both groups of firm sizes. For larger enterprises, the wage growth increased at a faster rate after the first month to slow down after one year of contract, indicating that the first month was faced as probation for the worker and after succeeding it, he or she would earn a wage increase.

The wage growth by economic sector revealed that the salaries in the industry increased less than other segments, in both size firms. For bigger companies this was also true for the financial sector, but not for the sales one. Social security contribution was inversed related with the labor income growth in the two groups of enterprises. This might be explained by the fact that it represents an indirect salary for the worker and a protection in the case he or she gets fired. Besides, when the firm decides to incur in such labor cost, it becomes more expensive to provide salary increase.

Finally we get to analyze the key variables to test if the predictions of the EW theory explain the wage differentials in Brazil, the proxies for labor effort: sub-occupied and sub-remunerated. The results from Table 3 show that the effort variables were statically significant and positively related with the wage growth, in the two groups of firms, an outcome compatible with the EW theory. However, the Wald test for the difference between the coefficients from different size firms was not statistically significant, for both types of variables. This result would imply that the Brazilian firms, independent of the amount of hired workers, indeed seek to remunerate labor effort, as a strategy to increase productivity. Nevertheless, the price paid for dispended effort isn't a sufficient force to explain the existence of wage discrepancy by firm size.

It is important to mention that, besides the association between labor effort and wages, the investments in education, as well as the permanence on the job for longer periods, can also be faced as re- 
sults derived from the EW theory. From one side, employers have incentive to pay more than the market-clearing wage in order to attract more productive and skilled labor, expecting to minimize the monitoring costs, and from the other side, the greater is the employee's fidelity to the firms, the less expenses the enterprise will face with labor turnover. We already argued that the monitoring costs and labor turnover the firms use to face represent proper incentives to induce firms to attract more qualified labor and individuals who would rather not shrink because the penalty for losing their jobs would be long spells of unemployment and the lost of the elevated salary.

Table 3 - Estimation for the wage growth between 2006 and 2007 by firm size

\begin{tabular}{|c|c|c|c|c|}
\hline \multirow{2}{*}{ VARIABLES } & \multicolumn{2}{|c|}{ SMALL } & \multicolumn{2}{|c|}{ MEDIUM AND LARGE } \\
\hline & COEF. & STAND. ERR & COEF. & STAND. ERR \\
\hline School variation & $0.2568^{* * *}$ & 0.0133 & $0.2868^{\star \star *}$ & 0.0062 \\
\hline Age & $-0.0174^{\star \star \star}$ & 0.0016 & $-0.0184^{\star \star \star}$ & 0.0008 \\
\hline Man & $-0.2582^{\star \star \star}$ & 0.0352 & $-0.2215^{\star \star \star}$ & 0.0167 \\
\hline Sub-occupied & $0.3209^{\star \star \star}$ & 0.1054 & $0.3424^{\star \star \star}$ & 0.0497 \\
\hline Sub-remunerated & $0.5566^{\star \star *}$ & 0.0529 & $0.6122^{* * *}$ & 0.0251 \\
\hline Social security contribution & $-0.2400^{\star \star \star}$ & 0.0416 & $-0.1284^{* * *}$ & 0.0197 \\
\hline Working for 1 month & $0.2829^{*}$ & 0.1455 & $0.1742^{* *}$ & 0.0676 \\
\hline 1 month to 1 year of work & $0.2087^{* * *}$ & 0.0423 & $0.2115^{\star * \star}$ & 0.0203 \\
\hline 1 to 2 years of work & $0.1405^{\star \star \star}$ & 0.0499 & $0.1828^{* * *}$ & 0.0240 \\
\hline Industry & $-0.1263^{\star \star}$ & 0.0507 & $-0.1055^{\star * *}$ & 0.0243 \\
\hline Construction & -0.0407 & 0.0805 & -0.0525 & 0.0389 \\
\hline Sales & 0.0439 & 0.0521 & $0.0733^{\star *}$ & 0.0253 \\
\hline Financial & -0.0731 & 0.0521 & $-0.0557^{\star *}$ & 0.0250 \\
\hline Public administration & 0.0538 & 0.0588 & 0.0443 & 0.0280 \\
\hline Recife & -0.0431 & 0.0741 & $-0.1203^{\star *}$ & 0.0378 \\
\hline Belo Horizonte & $0.3193^{\star \star *}$ & 0.0636 & $0.2293^{\star \star \star}$ & 0.0316 \\
\hline Rio de Janeiro & $0.3123^{\star \star \star}$ & 0.0596 & $0.1994^{\star \star \star}$ & 0.0304 \\
\hline São Paulo & $0.6418^{\star \star *}$ & 0.0629 & $0.4911^{\star \star \star}$ & 0.0302 \\
\hline Porto Alegre & $0.5149^{* * *}$ & 0.0662 & $0.3106^{* * *}$ & 0.0324 \\
\hline Constant & $1.5439^{\star \star \star}$ & 0.1299 & $0.4355^{\star \star \star}$ & 0.0469 \\
\hline
\end{tabular}

Bold coefficients for p-value: ${ }^{* *} p<0.01,{ }^{* *} p<0.05,{ }^{*} p<0.1$. 


\section{Conclusions}

The goal of this paper was to study if the wage differential between small and medium to large size firms in Brazil could be explained by the predictions of the EW theory, emphasizing the role of dispended labor effort and the wage premium. Using data from the Labor Monthly Survey (PME/ IBGE) for the years of 2006 and 2007, the following hypothesis was tested: large size firms pay higher wages because they tend to remunerate better the effort in order to minimize monitoring costs, which are greater when compared to smaller enterprises.

On such investigation we adopted empirical strategies based on a Switching Regression Model. On the first stage, probit estimations characterized the chances of working or not in a small size firm. Given the possible role of endogeneity involved in such decision of working or not in small firms, simultaneous equations models were estimated in order to incorporate the mentioned choice. These models were used to estimate the wage growth between 2006 and 2007 for the two groups of firms studied: small and medium/ large.

The obtained estimates corroborated the idea that the dedication to labor effort had a positive impact on the wage. Furthermore, the growth of schooling and the longer permanence of the worker on the firm were also directly related with the increase of wage. These results were largely favorable to the predictions of the EW theory on its shirking version; however, they were not sufficient to explain the existence of wage differentials in the Brazilian labor market.

\section{References}

Ahn, Joyup. 2006. Nonstandard Work in Japan and Korea-the Origin of Wage Differentials. Unpublished manuscript, Japan Institute for Labor Policy and Training, Tokyo.

Arbache, Jorge S. 2001. Wages Differentials in Brazil: Theory and Evidence. The Journal of Development Studies 38 (2) (December): 109-130.

Akerlof, George A. 1982. Labor Contracts as Partial Gift Exchange. Quarterly Journal of Economics 97 (4) (November): 543-69.

1984. Gift Exchange and Efficiency-Wage Theory: Four Views. American Economic Review, 74(2) (May): 79-83.

Akerlof, George A., and Janet L. Yellen. 1988. Fairness and Unemployment. American Economic Review, 78(2), (May): 44-49. 
Barth, James R., Joseph J. Cordes, and Sheldon E. Haber. 1987. Employee characteristics and firm size: are there systematic empirical relationships? Applied Economics, 19 (4), (April): 555-567.

Booth, Alison. L., Marco Francesconi, and Jeff Frank. 2000. Temporary Jobs: Stepping Stones or Dead Ends? Discussion Paper no. 205, The Institute for the Study of Labor (IZA), Bonn.

Bowles, Samuel. 1985. The Production Process in a Competitive Economy: Walrasian, Neo-Hobbesian, and Marxian Models. American Economic Review, 75(1), (March): 16-36.

Bradley, Steve., Colin Green, and Gareth Leeves, G. 2007. Employment Contracts and Effort: Why Do Temporary Workers Take Less Absence?. Unpublished manuscript. Economics Department, University of Lancaster, Lancaster.

Brown, Charles, and James Medoff. 1989. The employer size-wage effect. Working Paper, no. 2870, National Bureau of Economic Research, Cambridge, MA.

Cameron, A. C., And Parvin, K. Trivedi. 2005. Microeconometrics: Methods and Applications. $1^{\text {st }}$ ed. New York, Cambridge University Press.

Dickens, William T. 1986. Wages, Employment and the Threat of Collective Action by Workers. Working Paper no. 1856, National Bureau of Economic Research, Cambridge, MA.

Dickens, William T., and Lawrence F. Katz. 1987. Inter-Industry Wage Differences and Industry Characteristics. In Unemployment and the Structure of Labor Markets, eds Kevin Lang and Jonathan S. Leonard. Blackwell Publishing.

1987. Inter-Industry Wage Differences and Theories of Wage Determination Working Paper no. w2014, National Bureau of Economic Research, Cambridge, MA.

Engellandt, Axel., and Regina T. Riphahn. 2003 Temporary Contracts and Employee Effort. Discussion Paper no. 780, The Institute for the Study of Labor (IZA), Bonn.

Esteves, Luís . A. 2006. Uma Nota sobre Intensidade de Supervisão nas Indústrias Brasileiras. Revista Brasileira de Economia, 60 (3): 235-246.

Esteves, Luís. A. 2008. Salário Eficiência e Esforço de Trabalho: Evidências da Indústria Brasileira de Construção. Economia, 9 (2): 327-341.

Fox, Jeremy T. 2004. Employer-size wage gaps testing worker preferences and talents explanations, Unpublished manuscript, The University of Chicago.

Groshen, Erica L. 1986. Sources of Wage Dispersion: Does It Matter Where You Work? PhD. diss., Harvard University. 1986.

Groshen, Erica L, and Krueger, Alan B. 1990. The Structure of Supervision and Pay in Hospitals. Industrial and Labor Relations Review, 43 (3): 134-146.

Jimeno, Juan. F., and Luis, C, Toharia. 1996. Effort, Absenteeism, and Fixed Term Employment Contracts, Revista Espanola de Economia, 13(1): 105-119.

Krueger, Alan B., and Lawrence H. Summers. 1988. Efficiency Wages and the Inter-Industry Wage Structure. Econometrica, 56(2) (March): 259-93.

1987. Reflections on the Inter-Industry Wage Structure In Unemployment and the Structure of Labor Markets, eds Kevin Lang and Jonathan S. Leonard. Blackwell Publishing.

Lang, Kevin. 1988. Persistent Wage Dispersion and Involuntary Unemployment. Unpublished manuscript, Boston University.

Leibenstein, Harvey. 1957. The Theory of Underdevelopment in Densely Populated Backward Area in Economic Backwardness and Economic Growth, ed Harvey Leibenstein. Wiley: New York.

Maddala, G. S. 1983. Limited-Dependent and Qualitative Variables in Economics. $1^{\text {st }}$ ed. Cambridge University Press, Cambridge, UK.

Montgomery, James D. 1988. Equilibrium Wage Dispersion and Inter-Industry Wage Differentials. Unpublished manuscript, Massachusetts Institute of Technology, Cambridge. 
Oi, Walter Y. 1983. Heterogeneous Firms and the Organization of Production. Economic Inquiry, 21(2) (April):147-171.

Rebitzer, James, B. 1995. Is there a trade-off between supervision and wages? An empirical test of efficiency wage theory. Journal of Economic Behavior and Organization, 28: 107-129.

Romaguera, Pilar. 1991. Wage differentials and efficiency wage models: evidence from the Chilean economy. Working paper no. 153, Corporación de Investigaciones Económicas para América Latina, Santiago de Chile.

Roy, A. 1951. Some Thoughts on the Distribution of Earnings. Oxford Economic Papers, 3(2) (June): $135-146$.

Salop, Steven C. 1979. A Model of the Natural Rate of Unemployment. American Economic Review, 69(1) (March): 117-125.

Shapiro, Carl., and Joseph E. Stiglitz. 1984. Equilibrium Unemployment as a Worker Discipline Device. American Economic Review, 74(3) (June): 433-444.

Solow, Robert, M. 1979. Another Possible Source of Wage Stickiness. Journal of Macroeconomics, 1 (1) (Winter): 79-82. . 1980. On Theories of Unemployment. American Economic Review, 70(1) (March): 1-11.

Stiglitz, Joseph E. 1974. Alternative Theories of Wage Determination and Unemployment in LDCs: The Labor Turnover Model. Quarterly Journal of Economics, 8(2) (May): 194-227.

. 1985. Theories of Wage Rigidity In Keynes: Economic Legacy, eds James L. Butkiewicz, Kenneth J. Koford, and Jeffrey B. Miller. Praeger Publishres.

US Department of Commerce Bureau of the Census, 1988. Training, wage growth, firm size. The Survey of Income and Participation Program, n. 68. Washington, DC: U.S. Government Printing Office.

Weiss, Andrew. 1980. Job Queues and Layoffs in Labor Markets with Flexible Wages. Journal of Political Economy, 88(3) (June): 526-538.

Winter-Ebmer, Rudolf, and Josef Zweimüller. 1999. Firm Size Wage Differentials in Switzerland: Evidence from Job Changers. The American Economic Review, 89 (2) Papers and Proceedings of the One Hundred Eleventh Annual Meeting of the American Economic Association (May, 1999), pp. 89-93. 